\title{
Health Programming for Clergy An Overview of Protestant Programs in the United States
}

Amanda Wallace, M.Div.

Duke University Divinity School Duke University, Durham, NC

Rae Jean Proeschold-Bell, Ph.D. Duke Global Health Institute Duke Center for Health Policy and Inequalities Research Duke University, Durham, NC

Sara LeGrand, M.S.

Duke Center for Health Policy and Inequalities Research Duke University, Durham, NC

John James, M.A.

Robin Swift, M.P.H.

David Toole, Ph.D., M.T.S.

Matthew Toth, M.S.W.

Duke University Divinity School Duke University, Durham, NC

Please direct comments to Rae Jean Proeschold-Bell at rae.jean@duke.edu.

This is a pre-copy-editing, authorproduced PDF of an article accepted for publication in Pastoral Psychology following peer review. The full article citation is: Wallace, A., Proeschold-Bell, R.J., LeGrand, S., James, J., Swift, R, Toole, D., \& Toth, M. (2012). Health programming for clergy: An overview of Protestant programs. Pastoral Psychology, 61(113-143). DOI 10.1007/s11089-011-0382-3.

The final publication is available at www.springerlink.com:

http://www.springerlink.com/conte nt/p871u81190qn2357/.

\section{Abstract}

The health of clergy is important, and clergy may find health programming tailored to them more effective. Little is known about existing clergy health programs. We contacted Protestant denominational headquarters and searched academic databases and the Internet. We identified fifty-six clergy health programs and categorized them into prevention and personal enrichment; counseling; marriage and family enrichment; peer support; congregational health; congregational effectiveness; denominational enrichment; insurance/strategic pension plans; and referral-based programs. Only thirteen of the programs engaged in outcomes evaluation. Using the Socioecological Framework, we found that many programs support individual-level and institutional-level changes, but few programs support congregational-level changes. Outcome evaluation strategies and a central repository for information on clergy health programs are needed.

Keywords: clergy, health behavior, evaluation, health programs 


\section{Introduction}

The number of clergy in the United States (US) is substantial. The Yearbook of American and Canadian Churches estimates the number of clergy serving churches in the US in 2007 to be more than 622,000 (Lindner 2009). In 2006 in the US, there were roughly the same number of physicians and surgeons $(633,000)$ (U.S. Department of Labor 2009). Moreover, these clergy serve an estimated 339,000 churches with more than 152 million confirmed members, an estimated $50.1 \%$ of the US population at the end of 2007 (US Census Bureau 2009).

The clergy vocation is unique in its combination of responsibilities. Clergy preach and make meaning for their congregants. They perform sacramental rites and visit sick congregants. They have numerous administrative duties around the budget, fundraising, and personnel committees, and additionally assist with all church committees and ministries. Outside of their own church, clergy are frequently community liaisons and spokespersons. In addition, some clergy conduct counseling, and even those who do not intend to be counselors are often approached by congregants for their mental health needs. Among the many job descriptions that clergy are given by their congregants, they often act as caregivers to their congregants. Indeed, it's been show that pastor's are commonly used a source of support for mental health issues (Chalfant et al 1990). Overall, the job description of clergy has been found to be varied, busy, and unpredictable (Kuhne and Donaldson 1995). At the same time, clergy are committed to their vocation, and most profess that their position is a call from God, giving them deep passion for their vocation. This passion and commitment may make it difficult for clergy to set boundaries between work and personal life (Proeschold-Bell et al. 2009).

Based on their roles and call, it is not surprising that clergy report vocational satisfaction (Carroll 2006) and also stress (Rowatt 2001). The stressors of ministry are many and have been categorized into realms of personal criticism, boundary ambiguity, presumptive expectations, and family criticism (Lee and Iverson-Gilbert 2003). Demanding congregations have also been found to relate to lower pastor well-being and lower overall life satisfaction (Lee and Iverson-Gilbert 2003). Boiled down, the stressors faced by clergy are interpersonal in nature.

In addition to stress and emotional health, it is important to consider the physical health of clergy. The physical health of clergy was at one point considered to be excellent, due to favorable overall mortality rates for clergy (King \& Bailar 1969), however, certain disease-specific mortality rates, especially in the areas of hypertension and diabetes, are unfavorable for clergy (Flannelly et al 2002). Concern for clergy health is growing in light of new evidence that clergy may have higher disease rates than their non-clergy peers. In a study comparing United Methodist clergy in North Carolina to similar non-clergy North Carolinians, clergy had significantly higher rates of obesity, diabetes, hypertension, asthma, and arthritis (Proeschold-Bell and LeGrand 2010). The obesity rate for clergy was $40 \%$, compared to only $29 \%$ for North Carolinians. Because obesity is related to other health conditions (Nystad et al. 2004; Reynolds and Mcllvane 2009; Taylor et al. 2009), this high obesity rate for clergy portends high rates of future health problems. The combination of high stress and physical health diagnoses for clergy indicates the need for effective clergy health programs.

One way to look at clergy health programming is to consider it as a kind of employee health program. Employee-based health programs have been used, particularly among self-insured employers, to improve the health of their employees, and reduce health care costs for the employer. While there are significant 
methodological issues in evaluating the effectiveness of employee health programs ${ }^{1}$, there is evidence that employee health programs can improve health among employees and offer cost savings for the employers (Rothstein and Harrell 2009). Altogether, a review of employee health programs shows that they can be effective in increasing fruit and vegetable intake and decreasing fat consumption (Emmons et al. 1999; Perez et al. 2009), increasing daily physical activity (Block et al. 2004), and reducing risk behaviors over time (Prochaska et al. 2008). In addition, some studies point to a cost savings benefit for employers (Ozminkowski et al. 1999; Serxner et al. 2003; Stave et al. 2003). As such, health programs for clergy may offer similar benefits.

In 2007, we received foundation funding to design a health-promoting program for United Methodist pastors serving in the two annual conferences in North Carolina. In searching the literature for information on clergy health programming, we could not find any journal articles detailing health programs specific to clergy, much less articles reporting evaluation data for clergy-specific programs. This paper reports on the findings from our extensive efforts to identify and characterize Protestant clergy health programs in the United States. This information is needed to facilitate adoption of clergy health programs by interested parties, and to identify program aspects that both have and have not been tried with clergy. Given the important implications of the health of clergy, moving the state of clergy health programming forward may be beneficial to clergy and congregants alike.

\section{Methods}

We searched for clergy health programs in several ways, limiting our search to the United States and to Protestant denominations. First, we attempted to contact by phone the appropriate representative from the national headquarters of each of the following denominations: American Baptist Churches USA, United Church of Christ, Presbyterian Church of America, United Methodist Church, Evangelical Lutheran Church in America, Presbyterian Church (USA), Episcopal Church in the United States of America, and Christian Church (Disciples of Christ).

Second, we searched academic databases for articles or other writing on clergy health programs. We used the following terms in our searches: "clergy health programs," "clergy health," "clergy health studies," "clergy health and wellness," "church leadership health," "clergy health and wholeness," "clergy health initiatives," and "clergy consultation." Databases searched included: PubMed, Academic Search Premier, Academic One File, ISI Web of Science, ProQuest, LexisNexis, JSTOR, Web Science, and Google Scholar.

Third, using the same search terms, we used the Google search engine to locate websites related to clergy health programs. We used the contact information located on clergy health websites to contact program directors and liaisons to gain a fuller understanding of each program. We also asked to be directed to any other clergy health programs.

\section{Results}

\section{Program Identification and Categorization}

Through contacting national denomination headquarters, we learned that a number of denominations have a polity-wide focus on clergy health, usually sponsored by their benefit or pension programs. Apart from national programs, however, the bulk of such programming occurs regionally or within individual congregations.

\footnotetext{
${ }^{1}$ Very few evaluations are randomized controlled trails, and other issues involve not controlling for societal factors in changing behavior, the lack of a longitudinal analysis to evaluate health changes over time, and selection bias (Rothstein and Harrell 2009).
} 
Contact with denomination headquarters was thus an inefficient way to learn about clergy health programs. Searching academic databases was similarly unsuccessful and led us to conclude that few organizations publish formally documented information about their program components, structure, or evaluation. In contrast, searching through Google, we were able to find a number of websites on clergy health programs, and program staffs were often able to direct us to other clergy health programs.

Tables 1-5 provide an overview of the programs we identified. We categorized programs into four areas based on a modified version of the Socioecological Framework, a public health theory proposing that health behavior is the result of factors on five different levels: individual (e.g., personal beliefs); interpersonal (e.g., relationships with close significant others); community (e.g., norms among large groups of friends); institutional (e.g., work and business policies); and public policy (e.g., federal laws) (McLeroy et al. 1988). Proeschold-Bell and colleagues (2009) have adapted the Socio-ecological Framework specifically to United Methodist clergy, using the sociological levels of individual, interpersonal, congregational, and institutional. Many of the identified programs could be grouped into these categories.

\section{Individual-level Programs}

Prevention and personal enrichment. Programs in this category seek to prevent health problems by promoting renewal and providing time away from clergy tasks. An example is the Clergy Renewal Program, whose website indicates that "Renewal periods are not vacations, but times for intentional exploration and reflection, for drinking again from God's life-giving waters, for regaining the enthusiasm and creativity for ministry" (Clergy Renewal Program 2009).

Counseling. We found numerous private organizations that provide services to individual clergy, usually counseling for emotional issues or consultation about coping with a dysfunctional church. For example, the Mountain Learning Center Retreat offers group and one-on-one counseling sessions for clergy (Mountain Learning Center Retreat 2009).

\section{Interpersonal-level Programs}

Family and marriage support. We found several programs that intervene at the interpersonal level, most of which included interventions at the individual level as well. One notable program in this category is the Clergy Family Enrichment Committee Family Programs of the Virginia Conference of the United Methodist Church. The program offers opportunities for spouses, including a welcome dinner, an annual spouse retreat, and resources focused on life in the parsonage. Among other things, the committee has put together a "thrival kit" that is given to clergy at the beginning of their appointment to educate them and their families during the transition to a new church appointment.

Peer Support. Several programs provide clergy peer support in the form of group relationships that offer encouragement and support, and hold individuals accountable for their actions. Most of the retreat programs include a time in which clergy meet with peers. The Resource Center for Pastoral Excellence has established a Pastoral Sustenance Network for clergy to form peer groups.

\section{Congregational-level Programs}


Congregational health. We found several programs that focus on improving the functional health of congregations. The functioning of congregations can affect the health of the clergy who minister to those congregations (Proeschold-Bell et al. 2009).

For example, Healthy Congregations, based in Kansas, offers congregational self-assessments, covenants, and a report process to improve health within congregations and communities. Another program, Plowpoint Ministries, assesses a congregation's current functioning and addresses its specific needs based in one or more of the following: relational healing, visioning, ministry transitions, ministry team and staff development, leadership retreats, and congregational services team training.

Congregational effectiveness. We discovered several programs that focus on the effectiveness of the clergy person or the congregation as a whole. One such program is Sustaining Pastoral Excellence (SPE). SPE has dual goals of maintaining a high caliber of pastoral leaders and helping congregations to thrive, believing that pastors and congregations deeply affect each other. Some of SPE's activities include helping clergy create environments for ongoing biblical study, theological reflection, and spiritual renewal. SPE also helps clergy develop sustained friendships, which may be particularly beneficial for United Methodist Church pastors who frequently change church appointments through an itinerant system.

\section{Institutional-level Programs}

Insurance/Strategic Pension Plans. We found eight clergy health programs that were initiated by the pension or insurance plan provider for a particular denomination. The goals of such programs are to encourage clergy wellness and lower insurance rates. One example is the CREDO Institute, Inc., a collaborative alliance providing resources for leadership and wellness programs in the Episcopal Church. It is funded by the Church Pension Fund, the health and benefits office of its national polity. CREDO offers conferences in which attendees (over 3,000 since 1997) have an opportunity to discover new resources, examine their lives, and discover new identities, with the goal of promoting renewal at the individual level and that of the church at large (Maddox 2007). Periodically, the Institute writes a report on Episcopal Clergy Wellness that states a theology and model of wellness and systemic effects on clergy health. In 2007, the Presbyterian Church (USA) adapted the CREDO program model for its clergy, using funding from its Board of Pensions.

A second example is the insurance program within the Reformed Church of America. Its insurance program provides preventative health service coverage, including paying for stress reduction activities and providing access to other health resources such as health coaches. This program, Benefits for Life, reported insurance increases of only $2.5 \%$ per year for each of four years, compared to national rates of insurance increases of $8-10 \%$ per year. While it is impossible to attribute these cost savings solely to Benefits for Life, it is possible that the program played an important role.

Within the United Methodist Church (UMC), the General Conference established the General Board of Pensions and Health to supervise and administer the employee benefit plans. The General Board, in accordance with the provisions of The Book of Discipline (The United Methodist Church 2008), administers a plan called Health Flex for the benefit of its participants. Health Flex attempts to be a comprehensive approach to a healthier lifestyle, with features that support disease prevention, physical vitality, and emotional well-being. In addition to medical care coverage, Health Flex includes stress management services, financial and legal consultation, a physical activity program that delivers financial rewards, elder care services, health screenings, coaching services that address chronic conditions, and health information tools and resources. The General Board of Pensions and Health has also sponsored cross-denominational research on clergy health and instituted a national walking program. 
Referral-based. We found that many clergy health "programs" are general clearinghouses of information. Although many denominations do not establish formal clergy health programming, we found that many provide a listing of health resources that are available to both clergy and laity. Websites sponsored by local denominational conferences and districts often include a section devoted to wellness-"Health and Wellness," or "Health and Welfare" - that provides referral information on local resources, such as retreat locations and counseling services, for clergy and laity.

\section{Evaluation of Clergy Health Programs}

Of the fifty-six programs listed, we were able to gather information on evaluation activities for forty-one programs. Of those programs, nearly all indicated that they collected information to inform program improvement activities, also known as "process evaluation." Only thirteen programs reported that they were collecting information to examine mid-term or long-term changes resulting from the program, also known as "outcomes evaluation." Table 1 includes information on the kind of evaluation, if any, conducted.

\section{Impetus for Establishing Clergy Health Programs}

Although the impetus for starting clergy health programs was not one of our primary research questions, many program staff spontaneously broached the issue. We discovered two motivations for founding clergy health programs. The first motivation was experience of difficult pastoring that produced clergy stress and poorer health. For example, the Davidson Clergy Center was founded by a pastor and his spouse after the pastor experienced a church community that was mismatched with his strengths, leading to a disappointing pastorate for the family rather than to a joyous ministry. The Davidson Clergy Center offers a structured five-day program for clergy to find personal renewal through physical, spiritual, and emotional wellness efforts.

A second motivation for founding clergy health programs was rising health care costs. The Center for Health, managed by the United Methodist Church General Board of Pension and Health, initially thought health insurance costs were the main problem in skyrocketing health care costs. However, later they determined that increasing costs were also due to declines in clergy health. They seek to raise the collective health consciousness of UMC clergy and to pilot clergy health programs to improve clergy health.

Both of these motivations played a role in the creation of Duke Divinity School's Clergy Health Initiative (CHI). Over several years prior to 2006, The Duke Endowment (TDE), which by its 1924 indenture is charged in part with assisting in the maintenance and operation of the UMC in rural North Carolina, received a growing number of grant applications from UMC congregations and districts for projects designed to address the stress and poor health of UMC clergy. At the same time, TDE was in conversation with the leadership of both UMC annual conferences in North Carolina about the effects rising health insurance costs were having on churches, especially rural churches, and their ability to afford full-time pastors. Since both annual conferences are selfinsured, they did not have access to programming through the General Board of Pensions and Health. In 2006, TDE approached Duke Divinity School to explore the possibility of drawing on an emerging four-way partnership between TDE, each of the two annual conferences, and Duke Divinity School in order to create a comprehensive initiative that would both assess and seek to renew the health of UMC clergy in North Carolina.

In July 2007, TDE awarded a seven-year grant to the Divinity School for the purpose of developing and instituting, in collaboration with TDE and the two annual conferences, a comprehensive program of research and service aimed at improving the health of United Methodist pastors in the two North Carolina annual conferences, a group numbering around 1,600 full- and part-time pastors actively serving congregations. 


\section{Duke Clergy Health Initiative Program}

Funding from TDE has allowed the $\mathrm{CHI}$ broad latitude in conceiving both its programming and its research emphases. Further, its status as a program apart from the polity's benefits structure has given the $\mathrm{CHI}$ a measure of neutrality. The $\mathrm{CHI}$ began designing its interventions only after conducting a careful assessment of clergy health needs and preferences. This was accomplished through a four-month focus group process, the results of which were rigorously analyzed using grounded theory qualitative analysis. Pastors were asked to name the barriers and facilitators of health, to ascribe what impact the UMC pastoral life had on their health, and to outline what they wanted from a health program designed for them.

Having analyzed the focus group data, we developed a three-step pilot program that includes a physical examination and laboratory tests, health coaching, and small grants. With an eye toward holistic health care, Step 1 of this program provides pastors with a special form to give to their doctor during their physical exam. The form prompts doctors to ask their pastor-patients about mental health issues, sleep difficulties, and quality of life. Step 1 thus gets pastors thinking about health holistically. Importantly, it also provides them with information from their physician about their current health status, and offers sufficient time for them to understand how their physician views their current state of health.

In Step 2, pastors are matched with an experienced health coach. These health coaching sessions may occur in person or by phone. We contract only with health coaches who have national certification training and a deep understanding of clergy life; there are many health coaches who specialize in coaching pastors. During seven to fourteen sessions with their health coach, the pastors determine their own focus. Their health coaches, using their understanding of behavior change and motivational interviewing techniques, provide one-on-one support for change. Health coaches work with pastors to create coherence between their goals and values. Health coaches are attuned to mental health needs, and we trained our coaches to be aware of mental health stigma perceived by some pastors. We anticipate that health coaches will make referrals to mental health providers only after they have established rapport with their pastor-clients, and in a way that simultaneously recognizes stigma and normalizes experiences of stress, depression, or other such conditions.

Step 3 is designed to: (1) address the financial strain that pastors reported in focus groups; (2) create a system of accountability; and (3) through this system of accountability provide these United Methodist pastors with reasons and the means to think about their health in the theological context of their Wesleyan heritage. Central to ministry of John Wesley (d. 1791) and thus to the mission of early Methodism was a theological commitment to holistic health and healing, which was itself grounded in Wesley's understanding of salvation and the "holiness of heart and life" (Maddox 2007). Moreover, for Wesley "holiness" was inherently social; thus he organized his followers into "class meetings" or "bands" that met weekly for prayer, confession, and accountability. As a result of both Wesley's theology and his organizational innovations, United Methodist clergy have a rich theological and institutional heritage upon which to draw to support health behaviors and change. United Methodists have good resources for understanding health holistically (body, mind, and spirit) (United Methodist Book of Worship Committee, 1992) and for privileging the importance of accountability and the social character of wholeness and holiness (Byassee and Jones 2009). The pilot program of the CHI draws intentionally on this Wesleyan heritage as a motivation for sustained behavior change.

If pastors need additional financial resources to pursue their health change goals, they can apply for a small grant of up to $\$ 1,190$. A pastor's plan for the use of funds must be deemed sound and workable by the health coach and by at least three confidantes that the pastor chooses to be members of his or her "Wesleyan Band." Band members agree to support the pastor in his or her efforts to attain a health goal, and also to hold 
the pastor accountable by way of completing a monthly survey concerning the pastor's progress. We placed few restrictions on the use of grant funds (aside from the process described above) in order to be maximally responsive to pastors' needs. Grant requests have included reimbursement for health club membership fees, commercial diet plans, a new mattress, brief vacations for marital renewal, spiritual direction, and mental health service co-pays, to name a few.

The $\mathrm{CHI}$ selected two behavior change theories to guide the health coaches' work: Stages of Change theory (Prochaska and DiClemente 1982) and Motivational Interviewing (Miller and Rollnick, 2002). Using Stages of Change theory, health coaches do not expect pastors to enact behavior changes immediately; rather coaches guide pastors through stages of: (1) awareness of the need to change; (2) considering change; (3) planning to change; (4) making changes; and (5) maintaining changes. Motivational Interviewing uses simple techniques to keep the desire for behavior change in the hands of the pastor rather than the health coach. For example, if a pastor's goal is to exercise but her behavior does not reflect this goal, then the health coach may use techniques (such as developing the discrepancy between the pastor's stated goal and actions) to support the pastor's sense that she can make the changes she desires.

These behavior change theories are not specific to pastors. Instead, we considered it important to remember that pastors are human and to draw on the extensive research base of human behavior change. However, in addition to these theories we also drew on Leading Causes of Life (Gunderson and Pray 2004). Standing in a tradition of asset-based approaches to community development, Gunderson and Pray posit that a life- and assets-based approach to health behavior change may be more persuasive to participants than the litany of mortality and morbidity risks that characterizes a medical model approach to change. Common to all the theories that we have used to guide the coaches' work and our program more generally is the privileging of agency. Thus, our program design intends to foster participants' experiences of agency by allowing pastors to choose which behavior they want to work on, and which accountability partners they recruit. The $\mathrm{CHI}$ differs from existing clergy health programs in its degree of programming customization and in its high level of accountability. The pilot program involves two UMC districts. Eighty-five clergy $(70 \%$ of those eligible to participate) enrolled voluntarily. As part of this pilot, we will collect data on health behavior changes (such as self-reported exercise and diet) and health outcomes, including changes in blood pressure, cholesterol, and quality of life. If the data are promising, we plan to conduct a randomized controlled trial with a larger group of pastors.

\section{Discussion}

We found that a number of clergy health programs exist, with a variety of components and structures. We highlighted fifty-six programs specifically directed toward clergy health and categorized them in two ways. First, we categorized them based on their intended target level using the Socioecological Framework levels of individual, interpersonal, congregational, and institutional levels. Second, under each Socioecological Framework level, we categorized the kind of program through analysis of their components, structure, and mission (e.g., preventive health programs). Although it is unlikely that our listing of clergy health programs is exhaustive, we hope it will inform people interested in clergy health programs and also offer them ideas on whom to contact for more information.

The descriptive clergy health program data were limited by a lack of published information on clergy

health programs. When the opportunity for a personal connection via phone or email was available, we were able to gather more detailed information about the program. However, such connections are time-consuming 
and not always possible. Clergy and people interested in promoting clergy health would benefit from a single website that compiles information on clergy health programming.

Few clergy health programs conducted outcome evaluation. Many programs indicated that they conduct process evaluation, which generally helps improve participant satisfaction. The lack of health outcome evaluation data is severely limiting. In the absence of such data, it is impossible for persons interested in offering a clergy health program in their area to select a program with demonstrated effectiveness. Thirteen programs are currently engaged in outcome data collection, and we believe the field will benefit from their findings. Future clergy health programs, as well as ongoing clergy health programs, need resources to conduct evaluation.

Of the programs uncovered, many were conceived holistically, emphasized connection with others, and required few financial resources. Many of the programs were also retreat-based. We have three concerns about retreat-based health programming. First, the retreat format, often one to two weeks in duration, may be difficult for some pastors who feel pressure to minimize their time away from the church. Second, pastors may not have the financial flexibility to afford either the attendance costs or the transportation costs to and from the location. Third, retreats may fit into the busy and unpredictable schedules of pastors because they force pastors to block off several days. However, exercise and healthy eating need to be daily habits, and it is unclear the extent to which the retreat programs offer pastors suggestions on how to incorporate health practices into their day-to-day schedules.

We organized the program table based on the modified Socioecological Framework in part to determine whether clergy health programming exists at all levels. Intervening at more than one Socioecological Framework level has been shown to lead to better outcomes (Reger-Nash et al. 2006). It is encouraging that clergy health programs of all Socioecological Framework levels exist.

We found a number of institutional-level programs. Of the largest mainline denominations researched, all had health resources for clergy and laity alike, but few had programs tailored for clergy health. Notable exceptions are CREDO within the Episcopal Church Pension Fund and the Healthy Leaders Enhanced Lives Initiative within the Evangelical Lutheran Church of America.

Fewer programs specifically focused on the congregational level. The reason for fewer congregationallevel programs may be that it is easier to intervene with individuals (e.g., pastors) than congregations because of the dynamic culture of congregations. However, developing ways to enhance the functioning of congregations may be critically important to sustaining clergy health. There have been some popular writings, including Clergy Killers and The Toxic Congregation by Lloyd Rediger (Rediger 1997; Rediger 2007), on the negative impact that poorly functioning congregations can have on the health of pastors. In addition, through qualitative analysis of 11 clergy focus groups, we have identified three kinds of unhealthy congregations as categorized by clergy (Proeschold-Bell et al. 2009). These categories are: 1) congregants opposing even small changes suggested by a pastor; 2) congregations that are polarized along family lines, such as through historic disagreements between church families; and 3) intimidation and abuse of pastors, such as heckling pastors when they preach. We were glad to discover the Healthy Church Initiative in Columbia, Missouri, that may improve church functioning, but more programs are needed. For example, it may be fruitful to provide church committees, such as the parishpastor relation committees found in the United Methodist Church, with training on how to handle conflict and how to orient new pastors to the particular history of the church.

We learned that many Protestant churches and denominations have discovered a need for clergy health programming. For the most part, the programs represented in the table were developed in isolation from each other. With information on clergy health programs compiled in one place, it becomes possible for people designing these programs to consider ideas that have been implemented elsewhere, or to generate new ideas spawned by this overview. When conducting this review, we discovered that almost all clergy health program 
leaders wanted to learn about other clergy health programming in order to make their own program more effective.

The primary limitation of this study is that we limited our search to mainline Protestant denominations. It is possible that other faith communities have innovative clergy health programming. The strength of this study lies in the numerous phone calls to program staff throughout the United States. Though time-consuming, these calls deepened our understanding of programs and provided information on additional programs to contact.

\section{Conclusion}

A number of Protestant clergy health programs in the United States exist, but it appears that they are working in isolation from one another and that there is no central source to learn about different kinds of clergy health programs. Currently, evaluation and dissemination are lacking for clergy health programs. The next important steps are to implement and evaluate clergy health programs, and then disseminate them. The result will hopefully be a healthy and thriving pastorate.

\section{Acknowledgments}

The authors gratefully acknowledge the support offered by the representatives of the programs included in this paper; their time and information was invaluable for this compilation. The authors would also like to acknowledge the insightful comments made by Monica Rivers and Howard Moore. This study was funded by a grant from the Rural Church Program Area of The Duke Endowment. 
TABLE 1. CLERGY HEALTH PROGRAMS INTERVENING AT THE INDIVIDUAL LEVEL

\begin{tabular}{|c|c|c|c|c|c|c|c|}
\hline$\frac{\text { PROGRAM }}{\underline{\text { NAME }}}$ & $\begin{array}{l}\frac{\text { INSTITUTION NAME }}{\text { AND/OR LOCATION }} \\
\underline{\text { BASE }}\end{array}$ & $\begin{array}{c}\frac{\text { SPONSORING }}{\text { DENOMINATION }} \\
\text { DEN }\end{array}$ & $\begin{array}{l}\text { PROGRAM } \\
\text { COMPONENTS } \\
\end{array}$ & $\begin{array}{l}\text { PROGRAM } \\
\underline{\text { STRUCTURE }}\end{array}$ & EVALUATION & $\frac{\text { PROGRAM }}{\text { INCEPTION }}$ & INTENDED AUDIENCE \\
\hline $\begin{array}{c}\text { BIBLICAL } \\
\text { WELLNESS } \\
\text { MINISTRIES }\end{array}$ & $\begin{array}{l}\text { Raleigh, North } \\
\text { Carolina }\end{array}$ & $\begin{array}{c}\text { Multi- } \\
\text { denominational }\end{array}$ & $\begin{array}{l}\text { - Personal counseling } \\
\text { - Mental health consultation } \\
\text { - Health coaching } \\
\text { - Conflict management }\end{array}$ & $\begin{array}{l}\text { - Schedule and format varies depending on } \\
\text { individual's request }\end{array}$ & $\begin{array}{l}\text { Process Evaluation: } \\
\text { Not indicated } \\
\text { Outcome Evaluation: } \\
\text { None }\end{array}$ & 1987 & All Clergy \\
\hline CHARIS & $\begin{array}{l}\text { Wake Forest, North } \\
\text { Carolina }\end{array}$ & $\begin{array}{c}\text { Multi- } \\
\text { denominational }\end{array}$ & $\begin{array}{l}\text { - Group renewal retreats } \\
\text { - Counseling sessions } \\
\text { - Self-care, health education } \\
\text { seminars }\end{array}$ & $\begin{array}{l}\text { - Two-week retreats } \\
\text { - } 8 \text { participants per retreat } \\
\text { each day }\end{array}$ & $\begin{array}{l}\text { Process Evaluation: } \\
\text { Not indicated } \\
\text { Outcome Evaluation: } \\
\text { None }\end{array}$ & 1990 & $\begin{array}{c}\text { Clergy and } \\
\text { congregational leaders }\end{array}$ \\
\hline $\begin{array}{l}\text { CLERGY } \\
\text { RENEWAL } \\
\text { PROGRAM }\end{array}$ & $\begin{array}{l}\text { Lilly Endowment } \\
\text { Indianapolis, } \\
\text { Indiana }\end{array}$ & $\begin{array}{c}\text { Multi- } \\
\text { denominational }\end{array}$ & $\begin{array}{l}\text { - Proposed programs may } \\
\text { include: } \\
\text { o Sense of purpose } \\
\text { o Sense of balance } \\
\text { o Congregational support } \\
\text { o Benefit to the pastor and } \\
\text { organization }\end{array}$ & $\begin{array}{l}\text { - Given to organizations, not individuals, in } \\
\text { support of the renewal of clergy } \\
\text { - Grant application via proposal for funding } \\
\text { up to } \$ 50,000 \text { for a three to four month } \\
\text { especially designed renewal program }\end{array}$ & $\begin{array}{l}\text { Process Evaluation: } \\
\text { Personal reports } \\
\text { submitted post-renewal } \\
\text { program } \\
\text { Outcome Evaluation: } \\
\text { None }\end{array}$ & 2000 & $\begin{array}{c}\text { Clergy } \\
\text { (Master of Divinity } \\
\text { degree required) }\end{array}$ \\
\hline $\begin{array}{l}\text { COURAGE TO } \\
\text { SERVE }\end{array}$ & $\begin{array}{l}\text { Duke Divinity } \\
\text { School } \\
\text { Durham, North } \\
\text { Carolina }\end{array}$ & United Methodist & $\begin{array}{l}\text { - Spiritual and personal } \\
\text { formation } \\
\text { - Large and small group } \\
\text { discussions and activities } \\
\text { - Retreat and renewal } \\
\text { opportunities } \\
\text { - Exploration of soul and } \\
\text { vocational role } \\
\text { - Nurturing and discerning } \\
\text { identity and personal goals } \\
\text { - Vocational purpose } \\
\end{array}$ & $\begin{array}{l}\text { - } 18 \text {-month retreat format program, held } \\
\text { over } 5 \text { intermittent weekends during the } \\
\text { program timeframe } \\
\text { - Program participation is contingent on } \\
\text { being accepted through the application } \\
\text { process } \\
\text { - } 25 \text { participants per program }\end{array}$ & $\begin{array}{l}\text { Process Evaluation: } \\
\text { Post-retreat feedback } \\
\text { evaluation } \\
\text { Outcome Evaluation: } \\
\text { None }\end{array}$ & 1999 & $\begin{array}{l}\text { Rural clergy in North } \\
\text { Carolina United } \\
\text { Methodist Church }\end{array}$ \\
\hline $\begin{array}{l}\text { DAVIDSON } \\
\text { CLERGY CENTER } \\
\text { FIVE-DAY } \\
\text { RENEWAL } \\
\text { PROGRAM }\end{array}$ & $\begin{array}{l}\text { Davidson Clergy } \\
\text { Center } \\
\text { Davidson, North } \\
\text { Carolina }\end{array}$ & $\begin{array}{c}\text { Multi- } \\
\text { denominational }\end{array}$ & $\begin{array}{l}\text { - Individual and group } \\
\text { consultations } \\
\text { - Spiritual direction sessions } \\
\text { - Certified personal training } \\
\text { sessions } \\
\text { - Physical profile } \\
\text { interpretation } \\
\text { - Five-year development plan } \\
\text { after concluding five-day } \\
\text { renewal program }\end{array}$ & $\begin{array}{l}\text { - Five-day comprehensive renewal program } \\
\text { held at Davidson Clergy Center } \\
\text { - Mon-Fri, 8:00-5:30pm (evenings intended } \\
\text { for rest and relaxation) } \\
\text { - Six individuals per week }\end{array}$ & $\begin{array}{l}\text { Process Evaluation: } \\
\text { Post-program feedback } \\
\text { evaluation } \\
\\
\text { Outcome Evaluation: } \\
\text { Baseline survey } \\
\text { Three-month and nine- } \\
\text { month survey of } \\
\text { physical and mental } \\
\text { health }\end{array}$ & 2003 & $\begin{array}{c}\text { Clergy and } \\
\text { congregational leaders }\end{array}$ \\
\hline $\begin{array}{c}\text { THE } \\
\text { MINISTERIAL } \\
\text { PROFESSIONAL } \\
\text { PROGRAM }\end{array}$ & $\begin{array}{l}\text { Emory Clergy Care } \\
\text { Duluth, Georgia }\end{array}$ & United Methodist & $\begin{array}{l}\text { - Psychological and vocational } \\
\text { tests } \\
\text { - Pastoral skills training } \\
\text { - Work practices training }\end{array}$ & - Two-year commitment & $\begin{array}{l}\text { Process Evaluation: } \\
\text { Not indicated } \\
\text { Outcome Evaluation: } \\
\text { Not indicated }\end{array}$ & Not indicated & $\begin{array}{l}\text { Clergy and } \\
\text { congregational laity in } \\
\text { Georgia and Michigan }\end{array}$ \\
\hline $\begin{array}{l}\text { EMORY CLERGY } \\
\text { CARE PROGRAMS }\end{array}$ & $\begin{array}{l}\text { Emory Clergy Care } \\
\text { Duluth, Georgia }\end{array}$ & United Methodist & $\begin{array}{l}\text { - Discernment counseling and } \\
\text { consultation } \\
\text { - Vocational discernment and } \\
\text { re-envisioning } \\
\text { - Clergy family services }\end{array}$ & $\begin{array}{l}\text { - Services for these program components are } \\
\text { contracted out or provided on an individual } \\
\text { basis for clergy seeking renewal for } \\
\text { themselves or their family. }\end{array}$ & $\begin{array}{l}\text { Process Evaluation: } \\
\text { Not indicated } \\
\text { Outcome Evaluation: } \\
\text { Not indicated }\end{array}$ & Not Indicated & $\begin{array}{c}\text { Clergy } \\
\text { Congregational leaders }\end{array}$ \\
\hline
\end{tabular}




\begin{tabular}{|c|c|c|c|c|c|c|c|}
\hline $\begin{array}{l}\text { SABBATICAL } \\
\text { GRANTS FOR } \\
\text { PASTORAL } \\
\text { LEADERS }\end{array}$ & $\begin{array}{l}\text { Louisville Institute } \\
\text { at Louisville } \\
\text { Seminary, funded by } \\
\text { the Lilly } \\
\text { Endowment } \\
\text { Louisville, Kentucky }\end{array}$ & Presbyterian U.S.A & $\begin{array}{l}\text { Uniquely designed grant } \\
\text { proposal will have components } \\
\text { of: } \\
\text { - Vocational identity } \\
\text { - Refreshing body and spirit } \\
\text { - Rekindling habits of heart } \\
\text { and mind } \\
\end{array}$ & $\begin{array}{l}\text { - or } 12 \text { week sabbatical grants } \\
\text { Sabbatical themes engage topics such as: } \\
\text { spiritual practices, pastoral imagination, } \\
\text { worship, and the changing face of ministry. } \\
\text { - Attendance at the preparation consultation } \\
\text { - Up to forty grants each year } \\
\text { - Given to individuals or organizations } \\
\end{array}$ & $\begin{array}{l}\text { Process Evaluation: } \\
\text { Post-sabbatical } \\
\text { feedback evaluations } \\
\text { Outcome Evaluation: } \\
\text { None }\end{array}$ & 1994 & $\begin{array}{l}\text { All pastoral leader in } \\
\text { the United Stages and } \\
\text { Canada regular } \\
\text { employed in ministry }\end{array}$ \\
\hline $\begin{array}{l}\text { CLERGY HEALTH } \\
\text { INITIATIVE }\end{array}$ & $\begin{array}{l}\text { Duke Divinity } \\
\text { School, funded by } \\
\text { The Duke } \\
\text { Endowment } \\
\text { Durham, NC }\end{array}$ & United Methodist & $\begin{array}{l}\text { - Health Coaching } \\
\text { - Lab work } \\
\text { - Physical Exam } \\
\text { - Customized Wellness Plan } \\
\text { - Mini-grants paired with } \\
\text { accountability partners }\end{array}$ & $\begin{array}{l}\text { - Participants meet with health coach 7-12 } \\
\text { times to design a customized wellness plan } \\
\text { - Blood work and physical conducted at } \\
\text { baseline and } 6 \text { months. } \\
\text { - Participants can apply for mini-grants that } \\
\text { contribute to their wellness plan goals. }\end{array}$ & $\begin{array}{l}\text { Process Evaluation: } \\
\text { Feedback evaluation } \\
\text { from external evaluator } \\
\text { Outcome Evaluation: } \\
\text { Medical exam data, lab } \\
\text { data, and participant } \\
\text { survey data collected } \\
\text { at baseline and } 6 \\
\text { months. Participant } \\
\text { survey also repeated at } \\
12 \text { months. } \\
\end{array}$ & 2007 & $\begin{array}{l}\text { Clergy of the United } \\
\text { Methodist Church in } \\
\text { North Carolina }\end{array}$ \\
\hline $\begin{array}{l}\text { HEALTHY } \\
\text { TRANSITIONS } \\
\text { LEARNING } \\
\text { RETREATS }\end{array}$ & Richmond, Virginia & $\begin{array}{c}\text { Multi- } \\
\text { denominational }\end{array}$ & $\begin{array}{l}\text { - Wellness education: } \\
\begin{aligned} \text { o } & \text { Emotional } \\
\text { o } & \text { Physical } \\
\text { o } & \text { Personal } \\
\text { o } & \text { Professional }\end{aligned}\end{array}$ & $\begin{array}{l}\text { - Five-day retreats to help pastors choose } \\
\text { another direction and transfer their skills or } \\
\text { return to the ministry healed. }\end{array}$ & $\begin{array}{l}\text { Process Evaluation: } \\
\text { Post-retreat feedback } \\
\text { evaluation } \\
\text { Outcome Evaluation: } \\
\text { None }\end{array}$ & 1994 & $\begin{array}{l}\text { Clergy and clergy } \\
\text { spouses }\end{array}$ \\
\hline $\begin{array}{l}\text { RESTORATION } \\
\text { HOUSE }\end{array}$ & $\begin{array}{l}\text { Landrum, South } \\
\text { Carolina }\end{array}$ & $\begin{array}{c}\text { Multi- } \\
\text { denominational }\end{array}$ & $\begin{array}{l}\text { - Counseling and healing } \\
\text { retreat sessions }\end{array}$ & - Retreats consisting of 2-5 days & $\begin{array}{l}\text { Process Evaluation: } \\
\text { Post-retreat feedback } \\
\text { evaluation } \\
\text { Outcome Evaluation: } \\
\text { None }\end{array}$ & Not indicated & $\begin{array}{l}\text { Clergy of all } \\
\text { denominations }\end{array}$ \\
\hline $\begin{array}{c}\text { SELF-CARE } \\
\text { WORKSHOPS }\end{array}$ & $\begin{array}{l}\text { United Methodist } \\
\text { Health Ministry } \\
\text { Fund } \\
\text { Hutchinson, Kansas }\end{array}$ & United Methodist & $\begin{array}{l}\text { Information, discussion, self- } \\
\text { examination, and collaborative } \\
\text { support in the areas of: } \\
\text { - Mental/emotional health } \\
\text { - Physical health } \\
\text { - Social health } \\
\text { - Spiritual health }\end{array}$ & $\begin{array}{l}\text { - An 8-hour self-discover/self-care workshop } \\
\text { for clergy to cover the four health } \\
\text { component areas. Workshops are led by } \\
\text { trained professionals and church leaders and } \\
\text { offers time for presentation, discussion, self- } \\
\text { examination, and support. } \\
\text { - Clergy create 2-3 goals at the conclusion of } \\
\text { the workshop and commit to a personal self- } \\
\text { care covenant }\end{array}$ & $\begin{array}{l}\text { Process Evaluation: } \\
\text { Post-workshop } \\
\text { feedback evaluation } \\
\text { Outcome Evaluation: } \\
\text { Completed }\end{array}$ & 2000 & $\begin{array}{l}\text { United Methodist } \\
\text { Church Clergy }\end{array}$ \\
\hline SHEPHERD CARE & Atlanta, Georgia & $\begin{array}{c}\text { Multi- } \\
\text { denominational }\end{array}$ & $\begin{array}{l}\text { - Counseling and consultation } \\
\text { with trained professional on } \\
\text { the topics of health and self- } \\
\text { care } \\
\text { - Educational conference } \\
\text { - Resource publications } \\
\end{array}$ & $\begin{array}{l}\text { - Clergy and ministry leaders consult } \\
\text { Shepherd Care at their own discretion } \\
\text { - Programming tailored to individual needs } \\
\text { through partial day and three-day retreat } \\
\text { sessions }\end{array}$ & $\begin{array}{l}\text { Process Evaluation: } \\
\text { Post-session feedback } \\
\text { evaluation } \\
\text { Outcome Evaluation: } \\
\text { None }\end{array}$ & 1996 & $\begin{array}{l}\text { Clergy, congregational } \\
\text { leaders and all } \\
\text { Christian leaders }\end{array}$ \\
\hline $\begin{array}{l}\text { SONSCAPE } \\
\text { RETREATS }\end{array}$ & $\begin{array}{l}\text { Divide, CO } \\
\text { Rome, Georgia }\end{array}$ & $\begin{array}{c}\text { Multi- } \\
\text { denominational }\end{array}$ & $\begin{array}{l}\text { - Rest, renewal, Sabbath time } \\
\text { - Personal meditation time } \\
\text { - Group teaching sessions on } \\
\text { self-care } \\
\text { - Vocational and self-care } \\
\text { counseling } \\
\text { - Spiritual formation }\end{array}$ & $\begin{array}{l}\text { - One week } \\
\text { - Led by trained retreat leaders } \\
\text { - Three pastoral counseling sessions } \\
\text { - Daily devotions/meditations } \\
\text { - Group interaction and support }\end{array}$ & $\begin{array}{l}\text { Process Evaluation: } \\
\text { Annual evaluation } \\
\text { with the Board of } \\
\text { Visitors } \\
\text { Outcome Evaluation: } \\
\text { None }\end{array}$ & 1985 & $\begin{array}{l}\text { Clergy and all } \\
\text { Christian leaders }\end{array}$ \\
\hline
\end{tabular}




\begin{tabular}{|c|c|c|c|c|c|c|c|}
\hline $\begin{array}{l}\text { SABBATICAL } \\
\text { PLANNING }\end{array}$ & $\begin{array}{l}\text { Wheatridge } \\
\text { Ministries } \\
\text { WheatRidge, } \\
\text { Colorado } \\
\text { Itasca, Illinois }\end{array}$ & $\begin{array}{l}\text { Evangelical } \\
\text { Lutheran }\end{array}$ & $\begin{array}{l}\text { - Sabbatical consulting and } \\
\text { coaching } \\
\text { - Educational workshops on } \\
\text { self-care } \\
\text { - Conflict resolution including } \\
\text { conflict and management } \\
\text { change toolbox } \\
\text { - Ministry sabbatical resource } \\
\text { center } \\
\end{array}$ & $\begin{array}{l}\text { - Individual pastors contact Wheatridge } \\
\text { Ministries to get personal assistance with } \\
\text { designing a sabbatical program } \\
\text { - Accepted proposal receive grant funding for } \\
\text { program design to be executed. }\end{array}$ & $\begin{array}{l}\text { Process Evaluation: } \\
\text { Post-sabbatical } \\
\text { feedback evaluation } \\
\text { Outcome Evaluation: } \\
\text { Not indicated }\end{array}$ & 1992 & All clergy \\
\hline $\begin{array}{l}\text { CLERGY IN } \\
\text { KAIROS } \\
\text { PROGRAM }\end{array}$ & $\begin{array}{l}\text { The Pastoral } \\
\text { Institute } \\
\text { Columbus, Georgia }\end{array}$ & $\begin{array}{c}\text { Multi- } \\
\text { denominational }\end{array}$ & $\begin{array}{l}\text { - Personal, relational, spiritual, } \\
\text { and vocational assessments } \\
\text { - Psychological tests as needed } \\
\text { - Professional (vocational) } \\
\text { referrals } \\
\text { - Leadership development } \\
\text { - Learning retreats } \\
\text { - Lecture series for clergy } \\
\text { education }\end{array}$ & $\begin{array}{l}\text { - Weeklong; Sunday-Friday evening } \\
\text {-3 hours daily consultation }\end{array}$ & $\begin{array}{l}\text { Process Evaluation: } \\
\text { Feedback evaluation } \\
\text { and exit interviews } \\
\text { Outcome Evaluation: } \\
\text { Four Six-month } \\
\text { follow-up assessments } \\
\text { for each participant - in } \\
\text { progress }\end{array}$ & 1994 & $\begin{array}{c}\text { Ordained } \\
\text { clergypersons and } \\
\text { spouses }\end{array}$ \\
\hline $\begin{array}{l}\text { STILL WATERS } \\
\text { COUNSELING } \\
\text { MINISTRIES }\end{array}$ & New Lenox, Illinois & $\begin{array}{l}\text { Multi- } \\
\text { denominational }\end{array}$ & $\begin{array}{l}\text { - One-time and ongoing } \\
\text { consultation services } \\
\text { - Group consultation } \\
\text { - Personal spiritual exploration }\end{array}$ & $\begin{array}{l}\text { - Schedule varies depending on the } \\
\text { individual's request }\end{array}$ & $\begin{array}{l}\text { Process Evaluation: } \\
\text { None } \\
\text { Outcome Evaluation: } \\
\text { None }\end{array}$ & 2004 & $\begin{array}{l}\text { Clergy, professional } \\
\text { religious workers }\end{array}$ \\
\hline $\begin{array}{c}\text { CLERGY } \\
\text { CONSULTATION } \\
\text { SERVICE }\end{array}$ & $\begin{array}{l}\text { Kairos Institute } \\
\text { Madison, New } \\
\text { Jersey }\end{array}$ & $\begin{array}{l}\text { Multi- } \\
\text { denominational }\end{array}$ & $\begin{array}{l}\text { - Candidate Assessment for } \\
\text { Ordination } \\
\text { - Consultation and Counseling } \\
\text { for Clergy in Transition } \\
\text { - Organizational Consultation } \\
\text { to Judicatories } \\
\text { - Clergy Support Groups }\end{array}$ & $\begin{array}{l}\text { - Schedule and format varies depending on } \\
\text { individual's request }\end{array}$ & $\begin{array}{l}\text { Process Evaluation: } \\
\text { Not indicated } \\
\text { Outcome Evaluation: } \\
\text { Not indicated }\end{array}$ & 1987 & All clergy \\
\hline $\begin{array}{l}\text { SELF-CARE } \\
\text { COVENANT } \\
\text { WORKSHOPS }\end{array}$ & $\begin{array}{l}\text { Center for Health } \\
\text { Evanston, Illinois }\end{array}$ & United Methodist & $\begin{array}{l}\text { - Servant leadership and } \\
\text { impact on personal health } \\
\text { and well-being } \\
\text { - Health covenant to improve } \\
\text { one or more aspects of } \\
\text { physical, mental-emotional, } \\
\text { social or spiritual health. }\end{array}$ & - Two half-day sessions, eight hours total & $\begin{array}{l}\text { Process Evaluation: } \\
\text { Pre- and post- } \\
\text { participant feedback } \\
\text { Outcome Evaluation: } \\
\text { Annual reports and e- } \\
\text { mail follow-up } \\
\text { assessments } \\
\end{array}$ & 2006 & $\begin{array}{l}\text { Clergy of The United } \\
\text { Methodist Church }\end{array}$ \\
\hline $\begin{array}{l}\text { THE HEALTHY } \\
\text { BOUNDARIES } \\
\text { WORKSHOP }\end{array}$ & $\begin{array}{l}\text { Oregon-Idaho } \\
\text { Annual Conference } \\
\text { Portland, Oregon }\end{array}$ & United Methodist & $\begin{array}{l}\text { - Education on healthy } \\
\text { boundaries }\end{array}$ & $\begin{array}{l}\text { - Six-hour workshop held in two three-hour } \\
\text { sessions over a period of two days }\end{array}$ & $\begin{array}{l}\text { Process Evaluation: } \\
\text { Not indicated } \\
\text { Outcome Evaluation: } \\
\text { Not indicated } \\
\end{array}$ & 2007 & $\begin{array}{l}\text { Clergy and laity of the } \\
\text { Oregon-Idaho Annual } \\
\text { Conference }\end{array}$ \\
\hline $\begin{array}{l}\text { LEADERSHIP } \\
\text { DEVELOPMENT } \\
\text { JOURNEY } \\
\text { INITIATIVE }\end{array}$ & $\begin{array}{l}\text { Board of General } \\
\text { Superintendents of } \\
\text { The Wesleyan } \\
\text { Church }\end{array}$ & Wesleyan & $\begin{array}{l}\text { Four essentials: } \\
\text { o Relationships } \\
\text { o Action } \\
\text { o Commitment } \\
\text { o Energy }\end{array}$ & $\begin{array}{l}\text { - Updated available resources on a regular } \\
\text { basis }\end{array}$ & $\begin{array}{l}\text { Process Evaluation: } \\
\text { Not indicated } \\
\text { Outcome Evaluation: } \\
\text { Not indicated }\end{array}$ & 2002 & $\begin{array}{l}\text { Clergy of the } \\
\text { Wesleyan Church }\end{array}$ \\
\hline WELL INFORMED & $\begin{array}{l}\text { Guidestone } \\
\text { Insurance Plans } \\
\text { Dallas, Texas }\end{array}$ & Southern Baptist & $\begin{array}{l}\text { - Health and wellness } \\
\text { resources } \\
\text { o Wellness articles } \\
\text { o Family health topics } \\
\end{array}$ & $\begin{array}{l}\text { - Individual resources available as requested } \\
\text { to health insurance plan enrollees }\end{array}$ & $\begin{array}{l}\text { Process Evaluation: } \\
\text { Not indicated } \\
\text { Outcome Evaluation: }\end{array}$ & 2007 & $\begin{array}{c}\text { Enrollees of the } \\
\text { Southern Baptist } \\
\text { Guidestone Insurance } \\
\text { Plan } \\
\end{array}$ \\
\hline
\end{tabular}




\begin{tabular}{|c|c|c|c|c|c|c|c|}
\hline & & & $\begin{array}{l}\text { o Personal Health Manager } \\
\text { o Wellness program support }\end{array}$ & & None & & \\
\hline $\begin{array}{l}\text { SUSTAINING } \\
\text { SPIRITUAL } \\
\text { LEADERSHIP }\end{array}$ & $\begin{array}{l}\text { Academy for } \\
\text { Spiritual Leadership, } \\
\text { Center for Pastoral } \\
\text { Effectiveness of The } \\
\text { Louisiana } \\
\text { Conference } \\
\text { Baton Rouge, } \\
\text { Louisiana }\end{array}$ & United Methodist & $\begin{array}{l}\text { - Clergy Renewal } \\
\text { o } 1 \text {-2 month spiritual retreat } \\
\text { and reflection } \\
\text { - Pastoral Effectiveness } \\
\text { o Mentoring/coaching } \\
\text { o Long term wellness plan } \\
\text { o Accountability } \\
\text { o Clergy education, } \\
\text { formation and renewal } \\
\text { experiences } \\
\text { o Spiritual leadership }\end{array}$ & $\begin{array}{l}\text { - Pastors work with their mentors and } \\
\text { colleagues to develop a customized clergy } \\
\text { renewal plan for to be utilized in a } 1-2 \\
\text { month timeframe } \\
\text { - Soul Journey, part of clergy education and } \\
\text { formation, occurs when the clergy person } \\
\text { transitions from seminary to the pulpit } \\
\text { - Other resources are utilized at the discretion } \\
\text { of the clergy persona }\end{array}$ & $\begin{array}{l}\text { Process Evaluation: } \\
\text { Participant feedback } \\
\text { Outcome Evaluation: } \\
\text { Not indicated }\end{array}$ & 1990 & Not indicated \\
\hline
\end{tabular}


TABLE 2. CLERGY HEALTH PROGRAMS INTERVENING AT THE INTERPERSONAL LEVEL

\begin{tabular}{|c|c|c|c|c|c|c|c|}
\hline$\frac{\text { PROGRAM }}{\underline{\text { NAME }}}$ & $\begin{array}{l}\frac{\text { INSTITUTION NAME }}{\text { AND/OR LOCATION }} \\
\underline{\text { BASE }}\end{array}$ & $\begin{array}{c}\text { SPONSORING } \\
\text { DENOMINATION }\end{array}$ & $\begin{array}{c}\text { PROGRAM } \\
\text { COMPONENTS }\end{array}$ & $\begin{array}{l}\underline{\text { PROGRAM }} \\
\underline{\text { StRUCTURE }} \\
\end{array}$ & EVALUATION & $\begin{array}{l}\text { PROGRAM } \\
\text { INCEPTION }\end{array}$ & INTENDED AUDIENCE \\
\hline $\begin{array}{l}\text { CLERGY FAMILY } \\
\text { ENRICHMENT } \\
\text { COMMITTEE } \\
\text { FAMILY } \\
\text { PROGRAMS }\end{array}$ & $\begin{array}{l}\text { Virginia Conference } \\
\text { of the United } \\
\text { Methodist Church } \\
\text { Glen Allen, Virginia }\end{array}$ & United Methodist & $\begin{array}{l}\text { - Clergy family programs } \\
\text { o “Thrival Kit” } \\
\text { o Welcome dinner } \\
\text { o Annual spouses } \\
\text { o Luncheon } \\
\text { o Annual spouses' retreat } \\
\text { o Clergy spouse support } \\
\text { coordinators' program } \\
\text { o Parsonages support committee } \\
\text { resources }\end{array}$ & $\begin{array}{l}\text { - Clergy families receive a resource } \\
\text { notebook at beginning of program } \\
\text { involvement } \\
\text { - Clergy families receive } \\
\text { specialized help designed for } \\
\text { enrichment of clergy family }\end{array}$ & $\begin{array}{l}\text { Process Evaluation: } \\
\text { None } \\
\text { Outcome Evaluation: } \\
\text { None }\end{array}$ & 2002 & $\begin{array}{l}\text { Clergy and their } \\
\text { families of Virginia } \\
\text { United Methodist } \\
\text { Church Conference }\end{array}$ \\
\hline
\end{tabular}


TABLE 3. CLERGY HEALTH PROGRAMS INTERVENING A THE CONGREGATIONAL LEVEL

\begin{tabular}{|c|c|c|c|c|c|c|c|}
\hline$\frac{\text { PROGRAM }}{\underline{\text { NAME }}}$ & $\begin{array}{l}\frac{\text { INSTITUTION NAME }}{\text { AND/OR LOCATION }} \\
\text { BASE }\end{array}$ & $\begin{array}{c}\text { SPONSORING } \\
\text { DENOMINATION }\end{array}$ & $\begin{array}{c}\text { PROGRAM } \\
\text { COMPONENTS }\end{array}$ & $\begin{array}{c}\text { PROGRAM } \\
\text { STRUCTURE }\end{array}$ & EVALUATION & $\frac{\text { PROGRAM }}{\text { INCEPTION }}$ & INTENDED AUDIENCE \\
\hline $\begin{array}{c}\text { HEALTHY } \\
\text { CONGREGATIONS } \\
\text { PROGRAM }\end{array}$ & $\begin{array}{l}\text { United Methodist } \\
\text { Health Ministry } \\
\text { Fund } \\
\text { Hutchinson, Kansas }\end{array}$ & United Methodist & $\begin{array}{l}\text { Congregation self-assessment } \\
\text { - Health risk assessment } \\
\text { - Leadership instrument } \\
\text { - RE-AIM (Elements of health } \\
\text { behavior interventions) } \\
\text { o Reaching the target population } \\
\text { o Efficacy, effectiveness } \\
\text { o Adoption by target settings or } \\
\text { institutions } \\
\text { o Implementation } \\
\text { o Maintenance of intervention } \\
\text { effects in individuals and } \\
\text { populations over time }\end{array}$ & $\begin{array}{l}\text { - } \quad \text { Congregational identified team for } \\
\text { pre-application workshops } \\
\text { - Congregational covenant } \\
\text { - } \quad \text { Srant opportunities for enrichment } \\
\text { - Healthnual, regional team training } \\
\text { Hengregations Retreat }\end{array}$ & $\begin{array}{l}\text { Process Evaluation: } \\
\text { Feedback evaluation } \\
\text { from congregation } \\
\text { representative } \\
\text { Outcome Evaluation: } \\
\text { Baseline data } \\
\text { collection and one-year } \\
\text { follow-up collection }\end{array}$ & 1996 & $\begin{array}{c}\text { United Methodist } \\
\text { Church Congregations } \\
\text { (including clergy, staff, } \\
\text { congregants) }\end{array}$ \\
\hline $\begin{array}{l}\text { HEALTHY } \\
\text { CHURCH } \\
\text { INITIATIVE }\end{array}$ & $\begin{array}{l}\text { The Center for } \\
\text { Congregational } \\
\text { Excellence and The } \\
\text { Center for Pastoral } \\
\text { Excellence of The } \\
\text { Missouri Annual } \\
\text { Conference } \\
\text { Columbia, Missouri }\end{array}$ & United Methodist & $\begin{array}{l}\text { - Group leadership sessions } \\
\text { - Reading/reflection groups } \\
\text { - Peer Mentoring Groups } \\
\text { - Coaching } \\
\text { - Congregational Assessment }\end{array}$ & $\begin{array}{l}\text { - Two Track Program } \\
\text { o Pastor and Congregational } \\
\text { Development } \\
\text { o Small Church Academy: } \\
\text { - Approximately two years for full } \\
\text { introductory implementation } \\
\text { o Intervention Preparation } \\
\text { o Congregation Preparation } \\
\text { o Congregational Action }\end{array}$ & $\begin{array}{l}\text { Process Evaluation: } \\
\text { Interview sessions for } \\
\text { participant feedback } \\
\text { Outcome Evaluation: } \\
\text { Follow-up } \\
\text { prescriptions and } \\
\text { interventions as } \\
\text { applicable }\end{array}$ & 2007 & $\begin{array}{l}\text { Missouri Annual } \\
\text { Conference of The } \\
\text { United Methodist } \\
\text { Church Clergy and } \\
\text { Congregations }\end{array}$ \\
\hline
\end{tabular}


TABLE 4. CLERGY HEALTH PROGRAMS INTERVENING AT THE INSTITUTIONAL LEVEL

\begin{tabular}{|c|c|c|c|c|c|c|c|}
\hline$\frac{\text { PROGRAM }}{\underline{\text { NAME }}}$ & $\begin{array}{l}\frac{\text { INSTITUTION NAME }}{\text { AND/OR LOCATION }} \\
\text { BASE }\end{array}$ & $\begin{array}{c}\text { SPONSORING } \\
\text { DENOMINATION }\end{array}$ & $\begin{array}{c}\text { PROGRAM } \\
\text { COMPONENTS } \\
\end{array}$ & $\begin{array}{l}\text { PROGRAM } \\
\text { STRUCTURE } \\
\end{array}$ & EVALUATION & $\frac{\text { PROGRAM }}{\underline{\text { INCEPTION }}}$ & INTENDED AUDIENCE \\
\hline $\begin{array}{l}\text { AMAZING PACE } \\
\text { WELLNESS } \\
\text { PROGRAM }\end{array}$ & $\begin{array}{c}\text { Mississippi } \\
\text { Conference of The } \\
\text { United Methodist } \\
\text { Church } \\
\text { Jackson, Mississippi }\end{array}$ & United Methodist & $\begin{array}{l}\text { - Health progress measurement } \\
\text { using health monitoring tools } \\
\text { - Formation of church-based } \\
\text { encouragement teams } \\
\text { - Prepares program participants as } \\
\text { wellness leaders } \\
\text { - Virtual walking tours }\end{array}$ & $\begin{array}{l}\text { - One-year } \\
\text { - Participants set and achieve health } \\
\text { behavior goals } \\
\text { - Use of pedometers and interactive } \\
\text { website } \\
\text { - Sign Amazing Pace Covenant } \\
\text { - Blood pressure and weight } \\
\text { screenings throughout enrollment }\end{array}$ & $\begin{array}{l}\text { Process Evaluation: } \\
\text { None } \\
\text { Outcome Evaluation: } \\
\text { In progress }\end{array}$ & 2005 & $\begin{array}{l}\text { Mississippi Conference } \\
\text { health plan enrollees } \\
\text { (includes clergy and } \\
\text { laity) }\end{array}$ \\
\hline $\begin{array}{l}\text { BENEFITS FOR } \\
\text { LIFE }\end{array}$ & New York, New York & Reformed & $\begin{array}{l}\text { - Coverage: preventive health } \\
\text { services } \\
\text { - Educational information provided } \\
\text { by health resources } \\
\text { - Access to health coaches for } \\
\text { chronic conditions } \\
\text { - HeartMath Stress Reduction }\end{array}$ & & $\begin{array}{l}\text { Process Evaluation: } \\
\text { Not indicated } \\
\text { Outcome Evaluation: } \\
\text { Baseline and follow-up } \\
\text { assessments }\end{array}$ & 2006 & $\begin{array}{l}\text { Clergy and families } \\
\text { enrolled in the benefits } \\
\text { program. }\end{array}$ \\
\hline $\begin{array}{l}\text { CLERGY CARE } \\
\text { WELLNESS } \\
\text { PROGRAM }\end{array}$ & $\begin{array}{l}\text { Southwest Texas } \\
\text { Conference of } \\
\text { United Methodist } \\
\text { Church } \\
\text { San Antonio, Texas }\end{array}$ & United Methodist & $\begin{array}{l}\text { - Health risk assessment } \\
\text { - Lab work and assessment } \\
\text { : Wellness conversation } \\
\text { - Physical exam } \\
\text { - Webcasts of wellness } \\
\text { conversations will be available to } \\
\text { program enrollees (forthcoming) }\end{array}$ & $\begin{array}{l}\text { - One year } \\
\text { - Participants submit component cards } \\
\text { as they are completed } \\
\text { - Lab work completed at Annual } \\
\text { Conference }\end{array}$ & $\begin{array}{l}\text { Process Evaluation: } \\
\text { None } \\
\text { Outcome Evaluation: } \\
\text { None }\end{array}$ & 2005 & $\begin{array}{l}\text { Full-time clergy and } \\
\text { conference staff enrolled } \\
\text { in conference health } \\
\text { plan }\end{array}$ \\
\hline $\begin{array}{c}\text { DAY OF } \\
\text { WELLNESS }\end{array}$ & $\begin{array}{l}\text { Center for Clergy } \\
\text { Excellence - Texas } \\
\text { Annual Conference } \\
\text { of the United } \\
\text { Methodist Church } \\
\text { Houston, Texas }\end{array}$ & United Methodist & $\begin{array}{l}\text { Wellness Program includes: } \\
\text { : Nutrition Education and Practice } \\
\text { : Exercise 3x/week } \\
\text { - Pmall group spiritual participation } \\
\text { Assessonal coaching on Health Risk } \\
\text { Target Body Mass Index Screening, } \\
\text { - Strength building and flexibility } \\
\text { fitness sessions } \\
\text { - Stress management } \\
\text { - } \text { Annual physical } \\
\text { reaching target BMI of } 25 \text { for } \\
\text { Participants in Texas Annual } \\
\text { Conference Group Health Benefits } \\
\text { Program }\end{array}$ & $\begin{array}{l}\text { - The entry point into the Wellness } \\
\text { Program is the Day of Wellness - a } \\
\text { one-day event held 2x/year (January } \\
\text { and July) at Methodist Hospital } \\
\text { 9:00am-3:00pm } \\
\text { - Limited to } 40 \text { participants per day } \\
\text { - Includes six informative and } \\
\text { experiential sessions ( } 3 \text { in the am } \\
\text { and } 3 \text { in the pm) }\end{array}$ & $\begin{array}{l}\text { Process Evaluation: } \\
\text { Post-program feedback } \\
\text { evaluation and three } \\
\text { month follow-up } \\
\text { Outcome Evaluation: } \\
\text { None }\end{array}$ & 2008 & $\begin{array}{l}\text { Clergy and laity of } \\
\text { Texas Annual } \\
\text { Conference of the } \\
\text { United Methodist } \\
\text { Church }\end{array}$ \\
\hline $\begin{array}{l}\text { THE MINISTER'S } \\
\text { HEALTH AND } \\
\text { WELLNESS } \\
\text { PROGRAM }\end{array}$ & $\begin{array}{l}\text { Emory Clergy Care } \\
\text { Duluth, Georgia }\end{array}$ & United Methodist & $\begin{array}{l}\text { - Comprehensive physical health } \\
\text { examination } \\
\text { - Health enhancement planning }\end{array}$ & $\begin{array}{l}\text { - Clergy meet with Emory Clinic } \\
\text { physicians and allied health } \\
\text { professionals to develop a healthy } \\
\text { lifestyle plan } \\
\text { - \{Insert frequency/time\} } \\
\text { - } 678.924 .9260\end{array}$ & $\begin{array}{l}\text { Process Evaluation: } \\
\text { Not indicated } \\
\text { Outcome Evaluation: } \\
\text { Not indicated }\end{array}$ & Not indicated & $\begin{array}{l}\text { Georgia Conference } \\
\text { United Methodist } \\
\text { Church Clergy }\end{array}$ \\
\hline $\begin{array}{l}\text { HOLY HEALTHY } \\
\text { UMC }\end{array}$ & $\begin{array}{l}\text { Arkansas Conference } \\
\text { of the United } \\
\text { Methodist Church } \\
\text { Little Rock, Arkansas }\end{array}$ & United Methodist & $\begin{array}{l}\text { - Education and understanding of } \\
\text { personal health } \\
\text { - Personal health assessment } \\
\text { - Making and staying committed } \\
\text { through "Small Steps" modules }\end{array}$ & $\begin{array}{l}\text { - Clergy are invited to access health } \\
\text { resources at any time. } \\
\text { - Advanced involvement in this health } \\
\text { program includes completing a } \\
\text { personal commitment form to }\end{array}$ & $\begin{array}{l}\text { Process Evaluation: } \\
\text { None } \\
\text { Outcome Evaluation: } \\
\text { None }\end{array}$ & 2006 & $\begin{array}{l}\text { Clergy, staff and laity of } \\
\text { the Arkansas } \\
\text { Conference of the } \\
\text { United Methodist } \\
\text { Church }\end{array}$ \\
\hline
\end{tabular}




\begin{tabular}{|c|c|c|c|c|c|c|c|}
\hline & & & $\begin{array}{l}\text { (daily maintenance modules) } \\
\text { - Assessment, including tracking, } \\
\text { health tools, and physical check- } \\
\text { ups } \\
\text { - Action Tool Resources (for } \\
\text { emotional, spiritual, physical and } \\
\text { social health) }\end{array}$ & participate for an ongoing basis & & & \\
\hline $\begin{array}{l}\text { HEALTHY } \\
\text { LEADERS } \\
\text { INCENTIVE } \\
\text { PROGRAM }\end{array}$ & $\begin{array}{l}\text { North Central New } \\
\text { York Annual } \\
\text { Conference of the } \\
\text { United Methodist } \\
\text { Church } \\
\text { Cicero, New York }\end{array}$ & United Methodist & $\begin{array}{l}\text { - Healthy Leaders=Healthy } \\
\text { Churches mission } \\
\text { - Emphasis on preventable and } \\
\text { financial health care } \\
\text { - Wellness exam } \\
\text { - Health risk assessment } \\
\text { - Incentives }\end{array}$ & $\begin{array}{l}\text { - One-year } \\
\text { - Wellness exam during designated } \\
\text { calendar year } \\
\text { - Completion of Health Quotient } \\
\text { health risk assessment } \\
\text { - Complete participation allows for } \\
\text { eligibility to receive \$250 cash } \\
\text { incentive }\end{array}$ & $\begin{array}{l}\text { Process Evaluation: } \\
\text { None } \\
\text { Outcome Evaluation: } \\
\text { None }\end{array}$ & 2006 & $\begin{array}{l}\text { North Central New York } \\
\text { Annual Conference of } \\
\text { the UMC HealthFlex } \\
\text { insurance enrollees }\end{array}$ \\
\hline $\begin{array}{l}\text { VIRGIN HEALTH } \\
\text { MILES WALKING } \\
\text { PROGRAM }\end{array}$ & $\begin{array}{l}\text { Center for Health } \\
\text { Evanston, Illinois }\end{array}$ & United Methodist & $\begin{array}{l}\text { - Pedometer tracking and reporting } \\
\text { - Walking/physical activity }\end{array}$ & $\begin{array}{l}\text { - 12-month enrollment period } \\
\text { Each participant receives a } \\
\text { "GoZone" personal pedometer to } \\
\text { wear all the time and to track steps. } \\
\text { - Five different reward levels; } \\
\text { reaching a new program level allows } \\
\text { participants to earn HealthCash for } \\
\text { use at various retailers. }\end{array}$ & $\begin{array}{l}\text { Process Evaluation: } \\
\text { Not indicated } \\
\text { Outcome Evaluation: } \\
\text { Not indicated }\end{array}$ & TBD & $\begin{array}{c}\text { Health insurance } \\
\text { program participants } \\
\text { simultaneously enrolled } \\
\text { in Virgin HealthMiles } \\
\text { and HealthFlex program }\end{array}$ \\
\hline
\end{tabular}


TABLE 5. CLERGY HEALTH PROGRAMS INTERVENING AT MULTIPLE LEVELS

\begin{tabular}{|c|c|c|c|c|c|c|c|}
\hline$\frac{\text { PROGRAM }}{\underline{\text { NAME }}}$ & $\begin{array}{l}\frac{\text { INSTITUTION NAME }}{\text { AND/OR LOCATION }} \\
\text { BASE }\end{array}$ & $\begin{array}{c}\text { SPONSORING } \\
\text { DENOMINATION }\end{array}$ & $\begin{array}{c}\text { PROGRAM } \\
\text { COMPONENTS } \\
\end{array}$ & $\begin{array}{l}\text { PROGRAM } \\
\underline{\text { STRUCTURE }}\end{array}$ & EVALUATION & $\begin{array}{l}\text { PROGRAM } \\
\text { INCEPTION } \\
\end{array}$ & INTENDED AUDIENCE \\
\hline $\begin{array}{c}\text { CLERGY } \\
\text { WELLNESS } \\
\text { COMMISSION }\end{array}$ & $\begin{array}{l}\text { Episcopal Diocese of } \\
\text { California } \\
\text { San Francisco, } \\
\text { California }\end{array}$ & Episcopal & $\begin{array}{l}\text { - Training program for newly } \\
\text { ordained clergy } \\
\text { - Mentor program } \\
\text { - Clergy wellness support group } \\
\text { - Clergy wellness guide booklet, } \\
\text { "Clergy Wellness and Mutual } \\
\text { Ministry" } \\
\text { - Consultation for clergy and } \\
\text { congregations to promote } \\
\text { wellness } \\
\text { - Chaplain counseling } \\
\text { - Resource - Clergy wellness } \\
\text { website }\end{array}$ & $\begin{array}{l}\text { - Mentors assigned to a new clergy } \\
\text { when they start ministry } \\
\text { - Clergy Wellness group meeting on } \\
\text { the first Thursday of each month, } \\
\text { every other month for } 1.5 \text { hours }\end{array}$ & $\begin{array}{l}\text { Process Evaluation: } \\
\text { None } \\
\text { Outcome Evaluation: } \\
\text { None }\end{array}$ & 1997 & $\begin{array}{l}\text { All clergy and } \\
\text { congregations in the } \\
\text { Diocese of California }\end{array}$ \\
\hline $\begin{array}{c}\text { CREDO } \\
\text { CONFERENCES }\end{array}$ & $\begin{array}{c}\text { Credo Institute } \\
\text { Memphis, Tennessee }\end{array}$ & Episcopal & $\begin{array}{l}\text { - Education and discernment in } \\
\text { the wellness areas of : } \\
\text { - Spiritual health } \\
\text { - Vocational health } \\
\text { - Financial health } \\
\text { - Physical health } \\
\text { - Mental health }\end{array}$ & $\begin{array}{l}\text { Eight-day conferences } \\
\text { Begins with small groups and } \\
\text { presentation of material and then } \\
\text { concludes with creation of a } \\
\text { CREDO plan based on what the } \\
\text { clergy person would like to do - } \\
\text { goals. }\end{array}$ & $\begin{array}{l}\text { Process Evaluation: } \\
\text { Post-conference } \\
\text { feedback evaluation } \\
\text { Outcome Evaluation: } \\
\text { - } 5 \text { year longitudinal } \\
\text { study } \\
\text { - } \text { Pre/post personal } \\
\text { assessment } \\
\text { - } 6 \text { and } 12 \text { month } \\
\text { follow up }\end{array}$ & 1997 & $\begin{array}{c}\text { Episcopal and } \\
\text { Presbyterian Clergy }\end{array}$ \\
\hline $\begin{array}{l}\text { FIT TO LEAD } \\
\text { SEMINARY PILOT }\end{array}$ & $\begin{array}{l}\text { Center for Health } \\
\text { Evanston, Illinois }\end{array}$ & United Methodist & $\begin{array}{l}\text { - Personal health assessments } \\
\text { - Workshops based on personal } \\
\text { health assessments } \\
\text { - Self-care coaching } \\
\text { - Access to fitness facilities }\end{array}$ & $\begin{array}{l}\text { - Three seminaries } \\
\text { - Tracked over a three-year period } \\
\text { - Behavior change during academic } \\
\text { years is measured }\end{array}$ & $\begin{array}{l}\text { Process Evaluation: } \\
\text { Focus groups and } \\
\text { participant feedback } \\
\text { Outcome Evaluation: } \\
\text { Health coaches report } \\
\text { stages of change based } \\
\text { on online and Health } \\
\text { Risk Assessments }\end{array}$ & 2008 & Seminary students \\
\hline FRESH START & $\begin{array}{c}\text { Credo Institute } \\
\text { Memphis, Tennessee }\end{array}$ & Episcopal & $\begin{array}{l}\text { - "FreshStart" modules focused on } \\
\text { transition ministry } \\
\text { - Implementation plan for needs of } \\
\text { the respective diocese }\end{array}$ & $\begin{array}{ll}\text { - } & \text { Four-day national facilitator } \\
\text { training conferences (training for } \\
\text { trainers) } \\
\text { - Tuesday-Friday afternoons } \\
\text { - Periodic sessions at the local level }\end{array}$ & $\begin{array}{l}\text { Process Evaluation: } \\
\text { Post-training feedback } \\
\text { evaluation } \\
\text { Outcome Evaluation: } \\
\text { None }\end{array}$ & 2000 & $\begin{array}{l}\text { Episcopal clergy and } \\
\text { congregations }\end{array}$ \\
\hline LIFE OF LEADERS & $\begin{array}{c}\text { Center for } \\
\text { Excellence in Faith } \\
\text { and Health, } \\
\text { Methodist Le } \\
\text { Bonheur } \\
\end{array}$ & United Methodist & $\begin{array}{l}\text { - Health risk assessments } \\
\text { - Physician consultation } \\
\text { - Nutrition and exercise } \\
\text { consultation } \\
\text { - Life/health coaching } \\
\end{array}$ & $\begin{array}{l}\text { - Three-day assessment and retreat } \\
\text { workshop }\end{array}$ & $\begin{array}{l}\text { Process Evaluation: } \\
\text { Feedback from } \\
\text { participants } \\
\text { Outcome Evaluation: }\end{array}$ & 2007 & $\begin{array}{l}\text { United Methodist } \\
\text { Bishops and Clergy } \\
\text { and } \\
\text { All Clergy }\end{array}$ \\
\hline
\end{tabular}




\begin{tabular}{|c|c|c|c|c|c|c|c|}
\hline & Memphis, Tennessee & & & & $\begin{array}{l}\text { Evaluation for } \\
\text { programs outcome in } \\
\text { development process }\end{array}$ & & \\
\hline $\begin{array}{l}\text { MOUNTAIN } \\
\text { LEARNING } \\
\text { CENTER RETREAT } \\
\text { PROGRAM }\end{array}$ & $\begin{array}{l}\text { Mountain Learning } \\
\text { Center } \\
\text { June Lake, } \\
\text { California }\end{array}$ & Multi-denominational & $\begin{array}{l}\text { - Preventive health education } \\
\text { - Group therapy session } \\
\text { - Individual and/or couple } \\
\text { counseling }\end{array}$ & $\begin{array}{l}\text { - Two-week retreat } \\
\text { - Group sessions in the morning and } \\
\text { free time in the afternoon } \\
\text { - One-on-one sessions with a licensed } \\
\text { counselor throughout the retreat } \\
\text { - One Year of Quarterly Follow-up } \\
\text { Sessions }\end{array}$ & $\begin{array}{l}\text { Process Evaluation: } \\
\text { Post-retreat feedback } \\
\text { evaluation } \\
\text { Outcome Evaluation: } \\
\text { None }\end{array}$ & 1993 & $\begin{array}{l}\text { Clergy and clergy } \\
\text { spouses }\end{array}$ \\
\hline SHEPHERD CARE & $\begin{array}{l}\text { Plowpoint Ministries } \\
\text { High Point, North } \\
\text { Carolina }\end{array}$ & United Methodist & $\begin{array}{l}\text { - Spiritual coaching } \\
\text { - Leadership retreats }\end{array}$ & $\begin{array}{l}\text { - } 36 \text { week facilitated } \\
\text { journey/experience } \\
\text { - Six month coaching model } \\
\text { - One-on-one coaching } \\
\text { - Retreats designed to meet the needs } \\
\text { of ministry teams }\end{array}$ & $\begin{array}{l}\text { Process Evaluation: } \\
\text { Participant Feedback } \\
\text { evaluations } \\
\text { Outcome Evaluation: } \\
\text { Health measured at the } \\
\text { mid-point and } \\
\text { completion point of the } \\
\text { Shepherd Care } \\
\text { program }\end{array}$ & 2003 & $\begin{array}{l}\text { Clergy and } \\
\text { congregations of all } \\
\text { denominations }\end{array}$ \\
\hline $\begin{array}{l}\text { SUSTAINING } \\
\text { PASTORAL } \\
\text { EXCELLENCE }\end{array}$ & $\begin{array}{l}\text { Lilly Endowment } \\
\text { Indianapolis, } \\
\text { Indiana }\end{array}$ & Multi-denominational & $\begin{array}{l}\text { Uniquely designed program proposals } \\
\text { will have components of: } \\
\text { - Pastoral leadership development } \\
\text { - Spiritual growth opportunities } \\
\text { - Clergy renewal and/or study leave } \\
\text { - Peer study groups and networks } \\
\text { - Opportunities to explore other } \\
\text { ministries }\end{array}$ & $\begin{array}{l}\text { - Funding based on acceptance of } \\
\text { proposed program design } \\
\text { - Program is conducted over a 3-5 } \\
\text { year period }\end{array}$ & $\begin{array}{l}\text { Process Evaluation: } \\
\text { Post-assessment } \\
\text { reports } \\
\text { Outcome Evaluation: } \\
\text { None }\end{array}$ & $2002-2008$ & $\begin{array}{l}\text { Clergy and Christian } \\
\text { organizations }\end{array}$ \\
\hline $\begin{array}{l}\text { LIVING WELL } \\
\text { DAYS }\end{array}$ & $\begin{array}{l}\text { Wheatridge } \\
\text { Ministries } \\
\text { WheatRidge, } \\
\text { Colorado } \\
\text { Itasca, Illinois } \\
\end{array}$ & Evangelical Lutheran & $\begin{array}{l}\text { - Inspirational and educational } \\
\text { presentations } \\
\text { - Fellowship with other clergy } \\
\text { - Worship and singing }\end{array}$ & $\begin{array}{l}\text { - One-day workshop events for clergy } \\
\text { to relax and "get away" }\end{array}$ & $\begin{array}{l}\text { Process Evaluation: } \\
\text { Not indicated } \\
\text { Outcome Evaluation: } \\
\text { Not indicated } \\
\end{array}$ & 1992 & $\begin{array}{c}\text { Clergy and } \\
\text { congregational leaders }\end{array}$ \\
\hline $\begin{array}{c}\text { HEALTHY } \\
\text { LEADERS } \\
\text { ENHANCED LIVES } \\
\text { INITIATIVE }\end{array}$ & $\begin{array}{l}\text { Minneapolis, } \\
\text { Minnesota }\end{array}$ & $\begin{array}{l}\text { Evangelical } \\
\text { Lutheran }\end{array}$ & $\begin{array}{l}\text { - Strategy development } \\
\text { opportunities relating to } \\
\text { intentional wellness } \\
\text { - "EmbodyHealth” web portal } \\
\text { resources } \\
\text { - Completion of health risk } \\
\text { assessment } \\
\text { - Incentives for participating in } \\
\text { wellness health plan activities }\end{array}$ & $\begin{array}{l}\text { - All health plan enrollees are invited } \\
\text { to participate in health plan incentive } \\
\text { and other benefits on an ongoing } \\
\text { basis }\end{array}$ & $\begin{array}{l}\text { Process Evaluation: } \\
\text { None } \\
\text { Outcome Evaluation: } \\
\text { None }\end{array}$ & 2004 & $\begin{array}{l}\text { Clergy, congregations, } \\
\text { and congregational } \\
\text { leaders }\end{array}$ \\
\hline $\begin{array}{c}\text { CLERGY AND } \\
\text { CONSULTATION } \\
\text { CARE } \\
\end{array}$ & $\begin{array}{l}\text { Samaritan Institute } \\
\text { Denver, Colorado }\end{array}$ & Multi-denominational & $\begin{array}{l}\text { - Education, consultation, and } \\
\text { counseling services to clergy and } \\
\text { congregations }\end{array}$ & $\begin{array}{l}\text { - Schedule and format varies } \\
\text { dependent on individual or group's } \\
\text { request }\end{array}$ & $\begin{array}{l}\text { Process Evaluation: } \\
\text { Outcome Evaluation: }\end{array}$ & 2007 & $\begin{array}{l}\text { Clergy, Congregations, } \\
\text { and Judicatories }\end{array}$ \\
\hline $\begin{array}{l}\text { LIFE LISTENING } \\
\text { RESOURCES }\end{array}$ & Rochester, New York & Multi-denominational & $\begin{array}{l}\text { - Individual and group life and } \\
\text { health coaching } \\
\text { o Life practices } \\
\text { o Spiritual practices } \\
\text { o Personal practices } \\
\text { o Social practices }\end{array}$ & $\begin{array}{l}\text { - Individual sessions are one hour, } \\
\text { minimum of five sessions } \\
\text { - Group sessions include 5-8 } \\
\text { participants, five sessions } \\
\text { - Programs tailored to the needs of the } \\
\text { church. }\end{array}$ & $\begin{array}{l}\text { Process Evaluation: } \\
\text { Feedback from District } \\
\text { Superintendents and } \\
\text { other church leaders } \\
\text { Outcome Evaluation: } \\
\text { None }\end{array}$ & 2000 & $\begin{array}{l}\text { Clergy and church } \\
\text { leaders }\end{array}$ \\
\hline
\end{tabular}




\begin{tabular}{|c|c|c|c|c|c|c|c|}
\hline & & & - Leadership retreats & & & & \\
\hline $\begin{array}{l}\text { SUSTAINING } \\
\text { PASTORAL } \\
\text { EXCELLENCE } \\
\text { THROUGH } \\
\text { SCHOLARSHIP, } \\
\text { PIETY, AND } \\
\text { JUSTICE }\end{array}$ & $\begin{array}{c}\text { Memphis } \\
\text { Theological } \\
\text { Seminary } \\
\text { Memphis, Tennessee }\end{array}$ & Multi-denominational & $\begin{array}{l}\text { - Colleague groups (peer groups) } \\
\text { - Health and counseling resources }\end{array}$ & $\begin{array}{l}\text { - Working through small, diverse } \\
\text { colleague groups of pastors, } \\
\text { comprised of 8-10 persons, } \\
\text { - clergy participants covenant to join } \\
\text { together for three years of mutual } \\
\text { support. } \\
\text { - Pastors gather monthly for common } \\
\text { study, worship, seeking of justice, } \\
\text { and experiences of renewal. } \\
\text { - SPE initiated formation for ministry } \\
\text { groups for all entering students }\end{array}$ & $\begin{array}{l}\text { Process Evaluation: } \\
\text { Follow-up/feedback } \\
\text { evaluation at the } \\
\text { conclusion of the grant } \\
\text { cycle } \\
\text { Outcome Evaluation: } \\
\text { None }\end{array}$ & 2002 & $\begin{array}{l}\text { Clergy in the local } \\
\text { vicinity }\end{array}$ \\
\hline $\begin{array}{l}\text { SUSTAINING } \\
\text { PASTORAL } \\
\text { EXCELLENCE }\end{array}$ & $\begin{array}{l}\text { Minnesota Annual } \\
\text { Conference of the } \\
\text { United Methodist } \\
\text { Church } \\
\text { Minneapolis, } \\
\text { Minnesota }\end{array}$ & United Methodist & $\begin{array}{l}\text { - Accountability covenants } \\
\text { - Physical health improvement } \\
\text { - Colleague groups }\end{array}$ & - Not indicated & $\begin{array}{l}\text { Process Evaluation: } \\
\text { Follow-up/feedback } \\
\text { evaluation at the } \\
\text { conclusion of the grant } \\
\text { cycle } \\
\text { Outcome Evaluation: } \\
\text { None }\end{array}$ & 2002 & $\begin{array}{l}\text { Clergy of the Minnesota } \\
\text { Annual Conference of } \\
\text { the United Methodist } \\
\text { Church }\end{array}$ \\
\hline $\begin{array}{l}\text { RESOURCE } \\
\text { CENTER FOR } \\
\text { PASTORAL } \\
\text { EXCELLENCE }\end{array}$ & $\begin{array}{l}\text { Samford University } \\
\text { Birmingham, } \\
\text { Alabama }\end{array}$ & Baptist & $\begin{array}{l}\text { - The Pastor as Shepherd (Clergy } \\
\text { Renewal) } \\
\text { - Project Timothy (Future Clergy) } \\
\text { - Pastoral Sustenance Network } \\
\text { (Peer Groups) } \\
\text { - Women in Ministry Day Apart } \\
\text { (Retreat) }\end{array}$ & $\begin{array}{l}\text { - Clergy of all denominations are } \\
\text { invited to participate in any of the } \\
\text { program components. } \\
\text { - Each program components is } \\
\text { designed with a specific framework } \\
\text { to meet the specific needs of pastors. }\end{array}$ & $\begin{array}{l}\text { Process Evaluation: } \\
\text { Follow-up/feedback } \\
\text { evaluation at the } \\
\text { conclusion of the grant } \\
\text { cycle } \\
\text { Outcome Evaluation: } \\
\text { None }\end{array}$ & 2002 & $\begin{array}{l}\text { Clergy of any } \\
\text { denomination }\end{array}$ \\
\hline $\begin{array}{l}\text { HEALTH AND } \\
\text { WELLNESS } \\
\text { DEVELOPMENT } \\
\text { EDUCATIONAL } \\
\text { RESOURCES }\end{array}$ & $\begin{array}{l}\text { The Board of } \\
\text { Pensions of the } \\
\text { Presbyterian Church } \\
\text { (USA) } \\
\text { Philadelphia, } \\
\text { Pennsylvania }\end{array}$ & $\begin{array}{l}\text { Presbyterian Church } \\
\text { (USA) }\end{array}$ & $\begin{array}{l}\text { - Mayo Clinic Partnership } \\
\text { (EmbodyHealth web portal) } \\
\text { - Resource links to benefit plan } \\
\text { programs } \\
\text { - Partnership with behavioral health } \\
\text { program }\end{array}$ & $\begin{array}{l}\text { - Individuals participate in benefit } \\
\text { resources as necessary }\end{array}$ & $\begin{array}{l}\text { Process Evaluation: } \\
\text { Not indicated } \\
\text { Outcome Evaluation: } \\
\text { Not indicated }\end{array}$ & 2006 & Health plan enrollees \\
\hline $\begin{array}{l}\text { CENTER FOR } \\
\text { PASTORAL } \\
\text { EFFECTIVENESS } \\
\text { OF THE ROCKIES }\end{array}$ & $\begin{array}{l}\text { Remote Locations } \\
\text { Only }\end{array}$ & Multi-denominational & $\begin{array}{l}\text { - Leadership empowerment for } \\
\text { visioning and growth } \\
\text { - Focus on healthy congregational } \\
\text { practices } \\
\text { - Team and leadership development }\end{array}$ & $\begin{array}{l}\text { - Three program designs: } \\
\text { o Six retreats (18 } \\
\text { months) } \\
\text { o Eight retreats (One } \\
\text { year) } \\
\text { o Six retreats } \\
\text { o One-day seminars } \\
\text { - Retreats lead at remote locations as } \\
\text { needed }\end{array}$ & $\begin{array}{l}\text { Process Evaluation: } \\
\text { Not indicated } \\
\text { Outcome Evaluation: } \\
\text { None }\end{array}$ & 1999 & Clergy and lay leaders \\
\hline $\begin{array}{l}\text { THE PROGRAM IN } \\
\text { PASTORAL CARE } \\
\text { AND COUNSELING }\end{array}$ & $\begin{array}{l}\text { East Ohio Annual } \\
\text { Conference } \\
\text { Canton, Ohio }\end{array}$ & United Methodist & $\begin{array}{l}\text { - Personal counseling } \\
\text { o Wellness, self-care and } \\
\text { life/work balance } \\
\text { o Relational problems } \\
\text { o Spirituality and wholeness } \\
\text { o Life changing events } \\
\text { - Interpersonal counseling } \\
\text { o Marriage issues } \\
\text { o Family issues }\end{array}$ & $\begin{array}{l}\text { - Customized counseling services } \\
\text { based on personal needs }\end{array}$ & $\begin{array}{l}\text { Process Evaluation: } \\
\text { None } \\
\text { Outcome Evaluation: } \\
\text { None }\end{array}$ & 1968 & $\begin{array}{l}\text { Clergy, Christian } \\
\text { educators, conference } \\
\text { staff, spouses, and } \\
\text { dependent children }\end{array}$ \\
\hline
\end{tabular}




\begin{tabular}{|c|c|c|c|c|c|c|c|}
\hline $\begin{array}{l}\text { STANDARDS OF } \\
\text { EFFECTIVE } \\
\text { CLERGY } \\
\text { LEADERSHIP }\end{array}$ & $\begin{array}{l}\text { The Board of } \\
\text { Ordained Ministry, } \\
\text { Illinois Great Rivers } \\
\text { Conference } \\
\text { Springfield, Illinois }\end{array}$ & United Methodist & $\begin{array}{l}\text { - Spiritual, relational, wellness, } \\
\text { connectional, and leadership } \\
\text { support } \\
\text { - Discussion question }\end{array}$ & $\begin{array}{l}\text { - Standard discussion questions } \\
\text { presented to conference members for } \\
\text { use with personal disciplines, with a } \\
\text { partner or spiritual director, or with a } \\
\text { small group at one's own } \\
\text { discretion/timeline }\end{array}$ & $\begin{array}{l}\text { Process Evaluation: } \\
\text { None } \\
\text { Outcome Evaluation: } \\
\text { None }\end{array}$ & 2006 & $\begin{array}{l}\text { Clergy of the Illinois } \\
\text { Great Rivers Conference } \\
\text { of The United Methodist } \\
\text { Church }\end{array}$ \\
\hline $\begin{array}{l}\text { WELLNESS } \\
\text { PROGRAM }\end{array}$ & $\begin{array}{c}\text { Iowa Annual } \\
\text { Conference Board of } \\
\text { Pensions } \\
\text { Des Moines, Iowa }\end{array}$ & United Methodist & $\begin{array}{l}\text { - Accountability groups } \\
\text { - Weight-loss } \\
\text { - Incentives }\end{array}$ & $\begin{array}{l}\text { - Resources are available to form } \\
\text { accountability groups and personal } \\
\text { health practices }\end{array}$ & $\begin{array}{l}\text { Process Evaluation: } \\
\text { Not indicated } \\
\text { Outcome Evaluation: } \\
\text { Not indicated }\end{array}$ & $\begin{array}{c}\text { Not } \\
\text { indicated }\end{array}$ & $\begin{array}{l}\text { Clergy of the Iowa } \\
\text { Annual Conference of } \\
\text { The United Methodist } \\
\text { Church }\end{array}$ \\
\hline $\begin{array}{l}\text { COVENANT FOR } \\
\text { VITAL MINISTRY }\end{array}$ & $\begin{array}{l}\text { California-Pacific } \\
\text { Annual Conference } \\
\text { Pasadena, } \\
\text { California }\end{array}$ & United Methodist & $\begin{array}{l}\text { - Self-Assessment for Vital } \\
\text { Ministry } \\
\text { - Congregational Assessment } \\
\text { - Documented common } \\
\text { understanding between clergy and } \\
\text { congregation } \\
\text { - Customized plans for growth and } \\
\text { professional development } \\
\text { o Coaches } \\
\text { o Spiritual direction } \\
\text { o Psychotherapy } \\
\text { o Continuing education }\end{array}$ & $\begin{array}{l}\text { - Initial assessment and plan } \\
\text { completed during first year of } \\
\text { ministry } \\
\text { - Follow-up assessment completed } \\
\text { during subsequent years of ministry }\end{array}$ & $\begin{array}{l}\text { Process Evaluation: } \\
\text { Not indicated } \\
\text { Outcome Evaluation: } \\
\text { Not indicated }\end{array}$ & $\begin{array}{c}\text { Not } \\
\text { indicated }\end{array}$ & $\begin{array}{l}\text { Clergy of the California- } \\
\text { Pacific Annual } \\
\text { Conference of The } \\
\text { United Methodist } \\
\text { Church }\end{array}$ \\
\hline $\begin{array}{l}\text { HEALTHY } \\
\text { MINISTRY } \\
\text { WORKSHOP }\end{array}$ & $\begin{array}{l}\text { Ministerial Ethics } \\
\text { Committee, Iowa } \\
\text { Annual Conference } \\
\text { Des Moines, Iowa }\end{array}$ & United Methodist & $\begin{array}{l}\text { - Clergy Misconduct Workshops } \\
\text { - Sexual Misconduct } \\
\text { - Healthy Relations Workshops }\end{array}$ & $\begin{array}{l}\text { - Held every three years and } \\
\text { mandatory for every clergy person } \\
\text { serving in a local church in the } \\
\text { Conference. } \\
\text { - Annual workshop for new } \\
\text { professional coming in the } \\
\text { Conference. }\end{array}$ & $\begin{array}{l}\text { Process Evaluation: } \\
\text { Participant feedback } \\
\text { Outcome Evaluation: } \\
\text { Not indicated }\end{array}$ & 1980 & $\begin{array}{l}\text { Clergy of the Iowa } \\
\text { Conference of The } \\
\text { United Methodist } \\
\text { Church }\end{array}$ \\
\hline
\end{tabular}




\section{References}

Block, G., Block, T. Wakimoto, P. and Block, C. H. (2004). “Demonstration of an emailed worksite nutrition intervention program." Prevention of Chronic Disease: Public Health Research, Practice, and Policy 1, 1-13.

Byassee, J., \& Jones, G. (2009 November). Methodists \& microcredit. First Things. Retrieved from: http://www.firstthings.com/article/2009/10/methodists--microcredit.

Carroll, J. W. (2006). God's potters: Pastoral leadership and the shaping of congregations. Grand Rapids, MI, William B. Eerdmans Pub.

Chalfant, H.P., Heller, P., Robers, A., Briones, D., Aguirre-Hochbaum, S., Farr, W. (1990). "The clergy as a resource for those encountering psychological distress." Review of Religious Research 31, 305313.

Clergy Renewal Program. (2009). Retrieved from: http://www.clergyrenewal.org/.

Emmons, K. M, Linnan, L. A. , Shadel, W. G., Marcus, B. and Abrams, D. B. (1999). "The working healthy project: A worksite health promotion trial targeting phsyical activity, diet, and smoking. ." Journal of Occupational and Environmental Medicine 41, 545-555.

Flannelly, K. J., Weaver, A. J., Larons, D. B., \& Koenig, H. G. (2002). A review of mortality research on clergy and other religious professionals. Journal of Religion and Health, 41, 57-67.

Gunderson, G., \& Pray, L. (2004). Leading causes of life. Memphis, TN: The Center of Excellence in Faith and Health, LeBonheur Healthcare.

King, H., \& Bailar, J. C. (1969). The health of the clergy: A review of demographic literature. Demography, 6, 27-43.

Kuhne, G.W. \& Donaldson, J. F. (1995). Balancing ministry and management: An exploratory study of pastoral work activities. Review of Religious Research, 37(2), 147-163.

Lee, C. \& Iverson-Gilbert, J. (2003). Demand, support, and perception in family-related stress among protestant clergy. Family relations, 52(3), 249-257.

Lindner, E. W. (2009). Yearbook of American \& Canadian churches. Nashville, TN: Abingdon Press.

Maddox, R. L. (2007). John Wesley on holistic health and healing. Methodist History, 46, 4-33.

McLeroy, K. R., Bibeau, D., Steckler, A., \& Glanz, K. (1988). An ecological perspective on health promotion programs. Health Education Quarterly, 15, 351-377. 
Miller, W. R., \& Rollnick, S. (2002). Motivational interviewing: preparing people for change. New York: The Guilford Press.

Mountain Learning Center Retreat. (2009). Retrieved from: http://www.pastor-care.com/home.html.

Nystad, W., Meyer, H. E., Nafstad, P., Tverdal, A., Engeland, A. (2004). "Body mass index in relation to adult asthma among 135,000 Norwegian men and women." American Journal of Epidemiology 160, 969-976.

Ozminkowski, R.J., Dunn,R.L., Goetzel, R.Z., Cantor, R.I., Murnane, J. and Harrison, M. (1999). “A return on investment evaluation of the Citibank, N.A., health management program." American Journal of Health Promotion 14, 31-43.

Perez, A. P., Phillips, M. M., Cornell, C. E., Mays, G., and Adams, B. (2009). "Promoting dietary change among state health employees in Arkansas through a worksite wellness program: The health employee lifestyle program (HELP)." Prevention of Chronic Disease: Public Health Research, Practice, and Policy 6, 1-8.

Prochaska, J. O., \& DiClemente, C. C. (1982). Transtheoretical therapy: Toward a more integrative model of change. Psychotherapy: Theory, Research, and Practice, 19, 276-288.

Prochaska, J.O, Butterworth, S., Redding, C. A., Burden, V., Perrin, N., Leo, M., et al. (2008). "Initial efficacy of MI, TTM tailoring and HRI's with multiple behaviors for employee helath promotion." Preventive Medicine 46, 226-231.

Proeschold-Bell, R. J., LeGrand, S., James, J., Wallace, A., Adams, C., \& Toole, D. (2009). A theoretical model of the holistic health of United Methodist clergy. Journal of Religion and Health, doi:10.1007/s10943-009-9250-1.

Proeschold-Bell, R.J. \& LeGrand, S. (2010). "High rates of obesity and chronic disease among United Methodist clergy." Obesity 18(9), 1867-1870. DOI:10.1038/oby.2010.102.

Rediger, G. L. (1997). Clergy killers: guidance for pastors and congregations under attack. Louisville, KY, Westminister J. Knox Press.

Rediger, G. L. (2007). The toxic congregation: how to heal the soul of your church. Nashville, TN, Abingdon Press.

Reger-Nash, B., Bauman, A., Cooper, L., Chey, T., \& Simon, K. J. (2006). Evaluating communitywide walking interventions. Evaluation and Program Planning, 29, 251-259.

Reynolds, S.L. \& Mcllvane, J.M. (2009). "The impact of obesity and arthritis on active life expectancy in older Americans." Obesity 17, 363-369. 
Rothstein, M.A. \& Harrell, H.L. (2009). "Health risk reduction programs in employer-sponsored health plans: Part 1- Efficacy." Journal of Occupational and Environmental Medicine 51, 943-950.

Rowatt, G. W. (2001). "Stress and satisfaction in ministry families." Review \& Expositor 98 (4), 523-543.

Serxner, S. A., Gold,D. B., Grossmeier, J. J. and Anderson, D. R. (2003). "The relationship between health promotion program participation and medical costs: A dose response." Journal of Occupational and Environmental Medicine 45, 1196-1200.

Taylor, H.A., Coady, S.A., Levy, D., Walker, E.R., Vasan, R.S., Liu, J., et al.. (2009). "Relationships of BMI to cardiovascular risk factors differ by ethnicity." Obesity. E-pub ahead of print 19 November 2009.

The United Methodist Church. (2008). The Book of Discipline of The United Methodist Church. Nashville, TN: The United Methodist Publishing House.

U.S. Department of Labor. (2009). Occupational outlook handbook, 2008-2009 edition. Washington, DC: Bureau of Labor Statistics.

United Methodist Book of Worship Committee. (1992). The United Methodist book of worship. Nashville, TN: The United Methodist Publishing House.

US Census Bureau. (2009). Question \& answer center. Retrieved from: http://www.census.gov/population/www/index.html. 